This PDF is a selection from a published volume from the National Bureau of Economic Research

Volume Title: Tax Policy and the Economy, Volume 20

Volume Author/Editor: James M. Poterba, editor

Volume Publisher: The MIT Press

Volume ISBN: 0-262-16240-7

Volume URL: http://www.nber.org/books/pote06-1

Conference Date: September 15, 2005

Publication Date: September 2006

Title: Tax Reform and Entrepreneurial Activity

Author: Julie Berry Cullen, Roger Gordon

URL: http://www.nber.org/chapters/c0067 


\section{Tax Reform and Entrepreneurial Activity}

Julie Berry Cullen and Roger Gordon, University of California, San Diego

\section{Executive Summary}

The objective of this paper is to forecast the effects of plausible tax reforms on the extent of entrepreneurial activity in the United States. To do so, we draw on recent work we have done assessing the many routes through which the tax structure affects the amount of entrepreneurial activity, and estimating the responsiveness of behavior to these incentives. Using these estimates, we forecast that the effect of tax reforms on entrepreneurial activity can be very sensitive to whether or not current tax provisions aimed to encourage risk-taking in small firms remain part of the tax code. If they are left in place, we forecast that a shift to a Hall-Rabushka flat tax will leave the overall amount of entrepreneurial activity largely unaffected, although it will lead to a drop in activity among the highly skilled and an offsetting increase in activity among the less highly skilled. However, if in the process of fundamental tax reform, "net operating loss" carrybacks are disallowed, and section 1244 allowing capital losses on equity in small businesses to be reclassified as ordinary losses is repealed, then overall entrepreneurial activity could fall by more than half. The devil is in the details.

Tax reform will soon be at the top of the policy agenda, following the release of the tax reform proposals from the president's Tax Reform Commission. Tax reform has many possible objectives. The objective we focus on in this paper is to unleash the creative energies in the economy through making entrepreneurial activity more attractive. To what degree will any of the likely reforms that might be proposed help to encourage more entrepreneurial activity?

Why a focus on entrepreneurial activity per se? Going back at least to Schumpeter (1976), entrepreneurial activity has been viewed as the 
key source of economic growth. The presumption has been that individuals and firms, when they come up with new products, new processes, or new ways of organizing economic activity, generate far more benefits to society than they receive personally. As a result, the incentives that an individual faces to engage in entrepreneurial activity are inadequate.

The potential for such "externalities" is pervasive. The new ideas generated by an entrepreneur can often be copied by another firm. In many cases, the copying firm succeeds in capturing the market and the resulting profits. ${ }^{1}$ With competition, benefits are also shared with consumers through a lower price. New ideas can also make it easier for future entrepreneurs to identify profitable opportunities in other markets, benefits again not received by the initial entrepreneur. ${ }^{2}$ To the extent entrepreneurial activity generates such spillovers, there are economic grounds to try to intervene to encourage more such activity.

The tax system can provide this kind of encouragement in a variety of ways. Differential tax treatment of business versus wage and salary income or of losses versus profits can change the incentives to engage in a risky venture. In addition, entrepreneurial firms are normally closely held, in part due to lemons problems. ${ }^{3}$ Since an individual with a valuable idea for a new product and the skills needed to bring this idea to fruition may not be willing to impose the resulting risks on herself and her family, the misallocation of risks caused by these lemons problems implies less innovative activity. By absorbing a share of the losses as well as the profits, taxes help share the risks faced by entrepreneurs with other taxpayers and can thereby increase the amount of entrepreneurial risk-taking.

The focus of our recent research has been on assessing, both qualitatively and quantitatively, how the tax structure affects the amount of entrepreneurial activity. In this paper, we build on our past work to assess the degree to which past tax reforms have affected the aggregate amount of entrepreneurial activity. We then examine how possible tax reform proposals would likely affect the amount of entrepreneurial activity in the United States in coming years.

\section{What Is Entrepreneurial Activity?}

In order to assess the effects of the tax structure on entrepreneurial activity, the first task is to come up with some measure of the extent of entrepreneurial activity. The key concern is to measure behavior that 
generates externalities to others. Externalities presumably arise from new information about feasible technologies or organizational structures and their profitability.

Our presumption is that the key source of new ideas generating such spillovers is start-up firms. To begin with, any investment in a highly risky activity should initially be small to avoid putting too many funds at risk until more is known about the likely success of the project. It should also be much easier to produce an entirely new product or to produce a product in an entirely new way if one can design a firm from scratch around this concept rather than redesign an existing firm. Within an existing firm, employees have human capital invested in the production of existing products and existing internal forms of organization, while the shareholders have a financial claim on profits from existing products made obsolete by a new product, thus making both groups of stakeholders reluctant to shift course. Even if these stakeholders ultimately agree to try out a new product, the process of reaching this decision will take time, by which point a start-up will likely have seized the initiative. ${ }^{4}$

Not all start-up firms, of course, produce information of much value to others. For example, shifting from being an employee to being an independent contractor is simply an accounting change, with little or no change in real activity. To measure the extent of innovative activity in a start-up, we focus on the degree of risk-taking within such firms because producing new information is inherently risky. We then attempt to measure the degree to which the tax law affects risk-taking among start-up firms. ${ }^{5}$

\section{Taxes and Risk-Taking}

The most obvious element of the tax law that potentially affects innovative activity is the research and development $(R \& D)$ tax credit. Hall and Van-Reenen (2000) document that the credit has been effective in increasing the amount of R\&D activity in the United States. A key restriction with the existing credit, though, is that it is nonrefundable. This implies that it is of much less use to start-up firms since start-up firms have no current profits and may not have profits for many years on which tax liabilities can be reduced through use of the $R \& D$ credit. Even if the $R \& D$ credit is effective at encouraging $R \& D$ in existing profitable firms, it therefore provides little or no help in dealing with externalities generated by start-up firms. Yet according to the evidence 
reported in Bound et al. (1984), R\&D expenditures in small firms lead to patents at a much higher rate than do equivalent expenditures in larger firms, making it of particular value to encourage $R \& D$ in smaller firms.

There are many other ways in which the tax law can affect the amount of risk-taking in addition to the R\&D tax credit, however. To make clear these many other routes, we focus first on effects assuming that the entrepreneur is risk-neutral. We then examine what additional effects arise when the entrepreneur is risk-averse.

\subsection{Net Tax or Subsidy to Risk-Taking}

Assume then that the entrepreneur is risk-neutral. She currently earns a wage of, say, $\$ 100,000$ as an employee, but is considering becoming an entrepreneur instead. New businesses are very risky. To capture this, assume that the ex post income the individual would get as an entrepreneur has an equal chance of being $-\$ 100,000$ or $\$ 300,000$. In this simple example, mean income is unaffected by becoming an entrepreneur since $.5(-\$ 100,000+\$ 300,000)=\$ 100,000$, so that, ignoring taxes, this risk-neutral individual would be indifferent between the two options.

How do taxes affect this choice? Assume to begin that the individual has other income (perhaps spouse's income) of $\$ 150,000$, yielding adjusted gross income (AGI) of $\$ 250,000$ as an employee and either $\$ 50,000$ or $\$ 450,000$ as an entrepreneur. Consider first a very simple tax structure that provides $\$ 30,000$ in exemptions and deductions and that has a flat tax rate of 25 percent on all further income.

With such a constant marginal tax rate, the individual will continue to be indifferent to the choice between being an employee or an entrepreneur. The comparison is now between earning $250,000-$ $.25 * 220,000=195,000$ as an employee or earning an expected income of $.5[(50,000-.25 * 20,000)+(450,000-.25 * 420,000)]=195,000$ as an entrepreneur. Compared to being an employee, an entrepreneur can end up with either $\$ 200,000$ less income or $\$ 200,000$ more income pretax, and $\pm \$ 150,000$ after tax. The expected change in income from becoming an entrepreneur remains equal to zero. Ex ante, enough taxes are saved on any shortfall in income arising from self-employment to offset the extra taxes due when the business turns out to raise income on net.

To see these effects of the tax structure visually, examine figure 2.1, which compares the tax payments made by an employee (labeled $E$ ) 


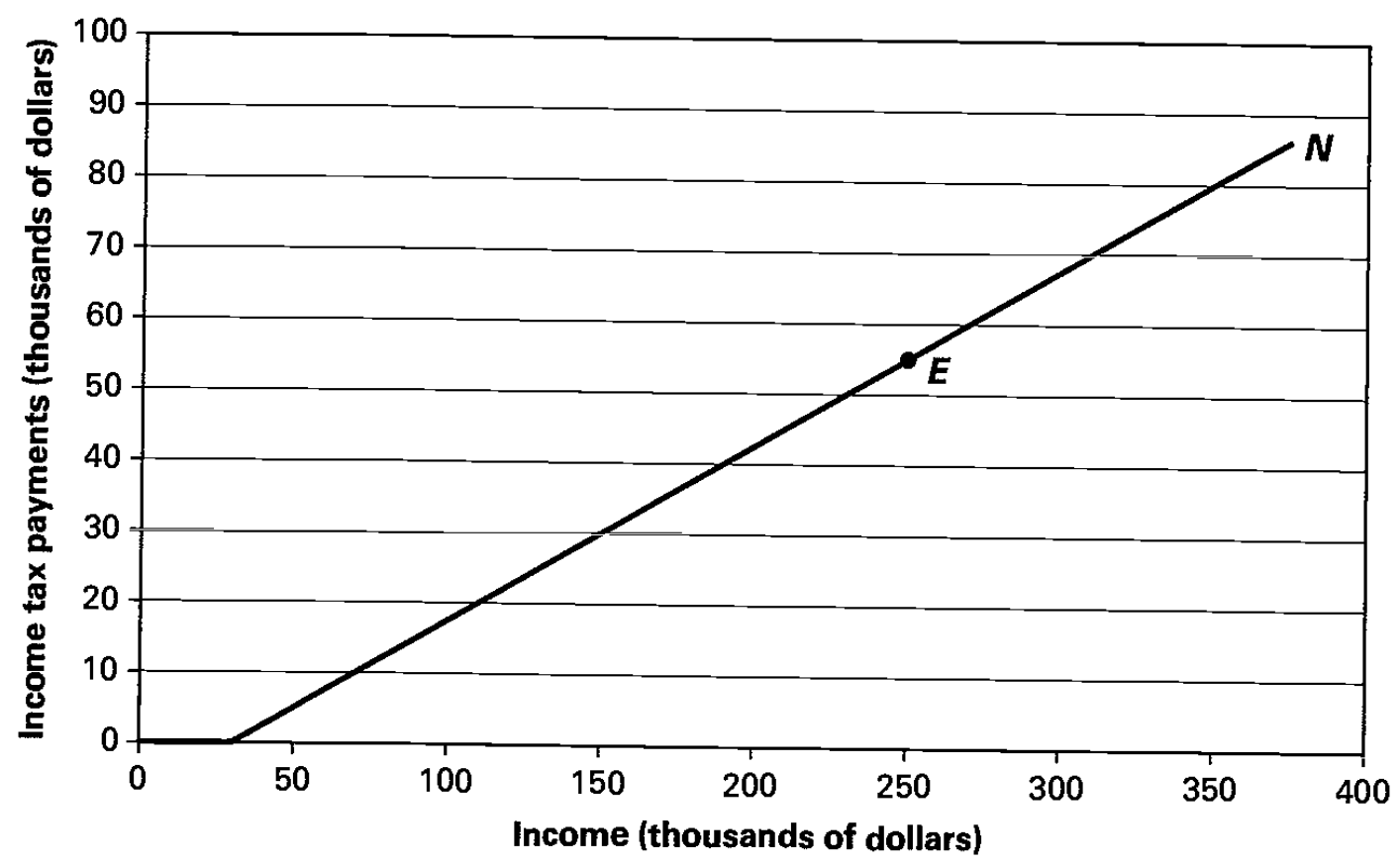

Figure 2.1

Tax Payments Under an Illustrative Proportional Income Tax

with the range of possible tax payments the individual owes if instead she becomes an entrepreneur (the line labeled $N$ ). If the individual is risk-neutral, then taxes distort the choice to take on entrepreneurial risk to the extent that the expected tax payments as an entrepreneur differ from those paid as an employee. In this example, if ex post AGI as an entrepreneur is always above $\$ 30,000$, so that the individual always faces a 25 percent marginal tax rate, and if expected entrepreneurial income equals income as an employee, then expected tax payments are unaffected by the choice to become an entrepreneur, or even the choice concerning how risky a project to pursue. The particular outcomes described in the above example satisfy both restrictions.

In general, though, any tax structure where the marginal tax rates vary over the relevant range of incomes can affect this individual's career choice. Consider, for example, a tax schedule in which any income between the exempt amount of $\$ 30,000$ and $\$ 140,000$ is taxable at a tax rate of 15 percent, while any income above that is taxable at a rate of 35 percent. By construction, the individual's after-tax income as an employee is still $\$ 195,000$. However, the individual's expected income after tax as an entrepreneur now drops to $\$ 186,000$. A risk-neutral individual will no longer find this project attractive enough to justify becoming an entrepreneur. Ex ante, any tax savings when the firm has losses no longer offset the additional taxes due if the firm turns out to 


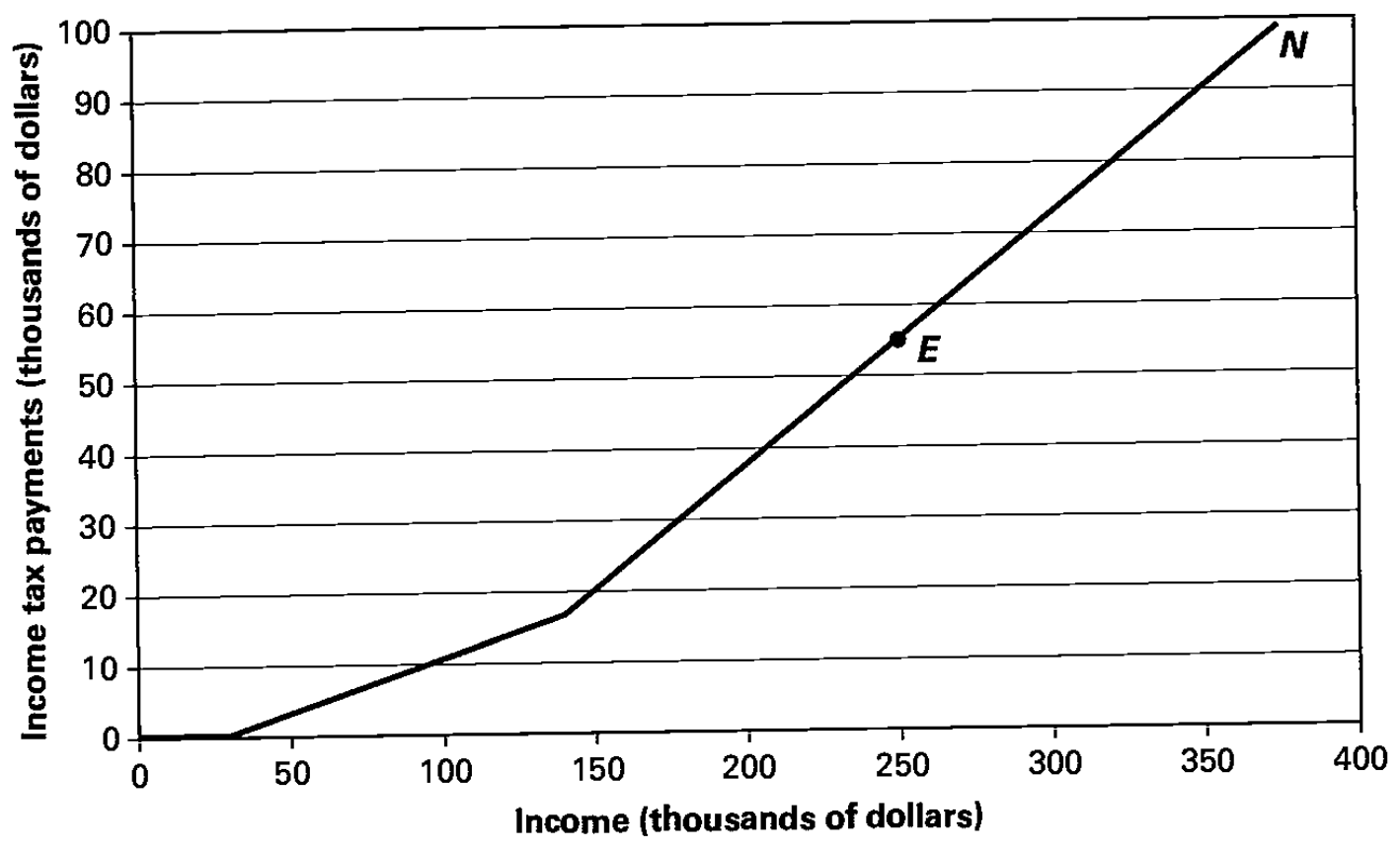

Figure $\mathbf{2 . 2}$

Tax Payments Under an Illustrative Progressive Income Tax

be successful. Given the less favorable tax treatment in this example, the profits when the firm is successful would need to increase to at least $\$ 327,700$ to be sufficient to induce the individual to consider becoming an entrepreneur.

Figure 2.2 compares the tax payments made by an employee versus an entrepreneur under this progressive tax schedule. With a progressive tax schedule, tax payments are a convex function of AGI. If the tax function $T($.) were strictly convex, we know that $E T(\tilde{Y})>T(E \tilde{Y})=$ $T\left(Y_{E}\right)$, where $\tilde{Y}$ denotes the random entrepreneurial income, and $Y_{E}$ denotes income as an employee. Taxes then discourage entrepreneurial activity. This result continues to hold, even if the tax schedule is only weakly convex, as long as there is some chance that the individual would end up in a different tax bracket as an entrepreneur than she would as an employee. In the example, this occurs as long as there is some chance that the individual's AGI will end up below $\$ 140,000$.

The higher the probability that the individual will end up in a different tax bracket than she would as an employee, and the greater the difference between the tax rates, the larger is the tax penalty for becoming an entrepreneur. The probability of ending up in a different tax bracket will vary depending on the initial income level of the entrepreneur and the amount of risk faced by the firm. If the firm had been less risky in the above example, yielding a pretax return that is always above 
$\$ 140,000$, then the tax law is again neutral-labor income is simply taxed at a marginal rate of 35 percent, regardless of its form. Conversely, if the firm is even riskier, then the tax penalty arising from the progressive tax schedule becomes more important. Consider, for example, the choice whether to start up a business with payoffs of $-\$ 100,000$ and $\$ 300,000$ or one with payoffs of $-\$ 100,100$ and $\$ 300,100$. A riskneutral individual would be indifferent if taxes are not a factor. With a constant marginal tax rate, of say, 35 percent, the two choices remain equally attractive. But under the progressive tax schedule described above, the extra losses are $(1-.15) \times 100$ while the extra profits are only $(1-.35) \times 100$, implying a net expected loss of $\$ 10$ on the extra risk. Progressive taxes therefore discourage this extra risk-taking for individuals who have already decided to start a new business. Here the net tax penalty depends directly on the difference in the relevant marginal tax rates: per dollar of extra spread in outcomes, the net expected gain is $.5 \times((1-.35)-(1-.15))=.5 \times(.15-.35)$.

The tax penalty on risk-taking also varies depending on the income level of the individual. For an individual with higher outside income, pushing point $E$ in figure 2.2 to the right, the probability of ending up with AGI in a different tax bracket drops; it rises if the individual has lower outside income. With a symmetric distribution of possible outcomes, the tax penalty on entrepreneurial activity would be greatest for an individual with income as an employee exactly at the kink point. $^{6}$

The existing personal income tax includes many other provisions, in addition to the basic rate structure, that either exacerbate or lessen this tax distortion. The most important examples are probably the earned income tax credit (EITC), the payroll tax, and the option firms face to incorporate rather than to operate in noncorporate form.

Consider first the implications of the EITC. Due to the credit, an entrepreneur with a child faces more than a 30 percent subsidy to her net wage and/or self-employment income up to roughly $\$ 10,000$, no taxes on subsequent income until $\$ 15,000$, then a surtax of roughly 20 percent until the credit has been fully repaid (which with these figures occurs at an income of $\$ 30,000$ ).

Introducing the EITC causes a shift in the tax schedule from that appearing in figure 2.2 to that seen in figure 2.3. Two new convex kinks are introduced at incomes of $\$ 10,000$ and $\$ 15,000$. Each of these convex kinks creates a penalty to risk-taking for the same reasons as occurred when the convex kink was created at an income of $\$ 140,000$ 


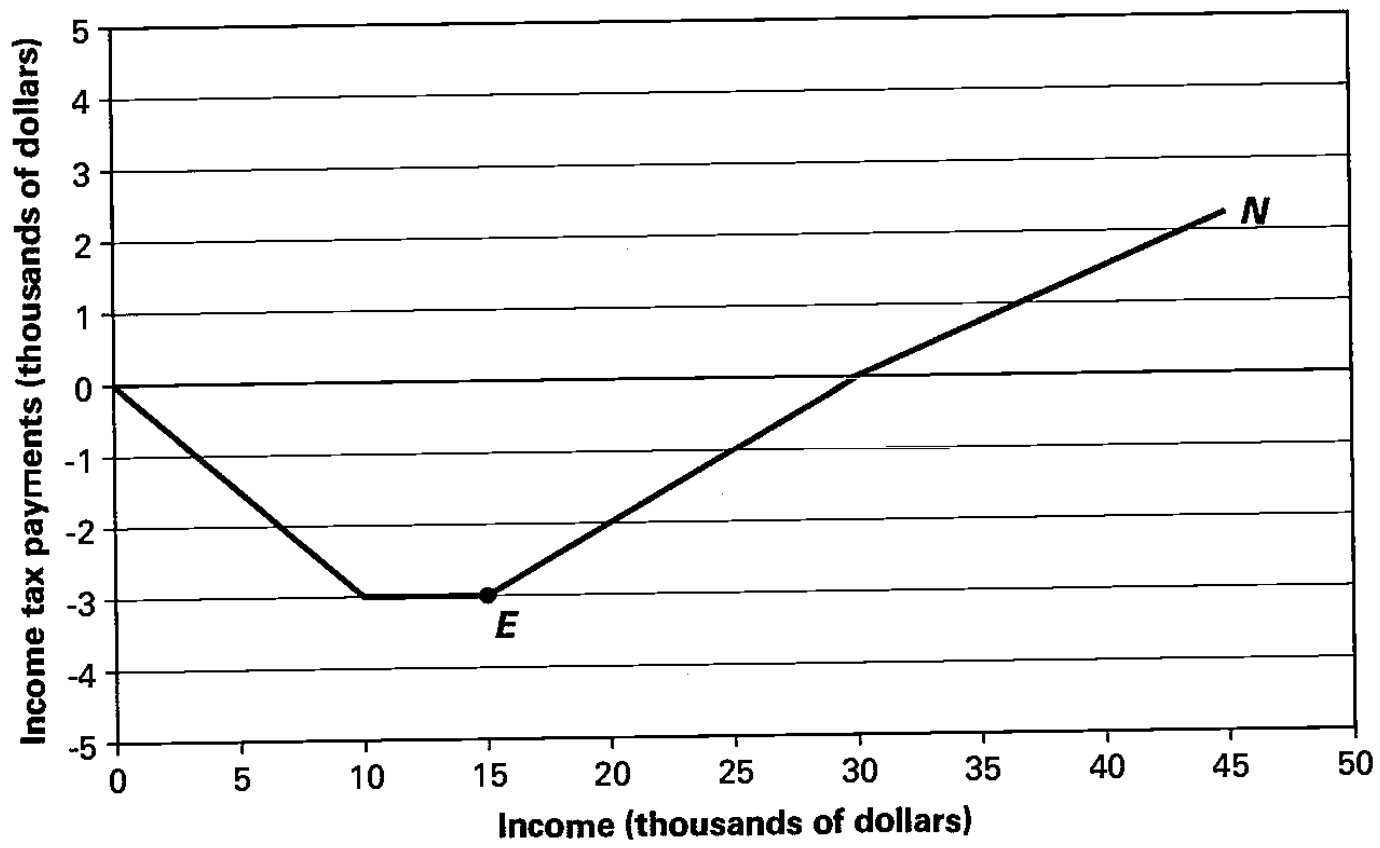

Figure 2.3

Tax Payments Under an Illustrative EITC

(when we shifted from a proportional to a progressive rate structure). For example, consider an individual with labor income of $\$ 15,000$ (and no other sources of income), a point labeled $E$ in figure 2.3 , who might instead become an entrepreneur earning either $\$ 5,000$ or $\$ 25,000$ pretax. Taking advantage of the EITC, as an employee this individual would receive $\$ 18,000$. As an entrepreneur, however, this individual's expected income is only $.5(\$ 6,500+\$ 26,000)=\$ 16,250$. Taxes also discourage extra risk-taking by this potential entrepreneur. If the firm could instead have payoffs of $\$ 4,900$ or $\$ 25,100$, the expected pretax income on the extra risk is $\$ 0$, but the change in expected after-tax income from taking on the added risk is $-\$ 25$ ! The EITC strongly discourages risk-taking for such individuals.

In addition, however, the EITC converts the convex kink at $\$ 30,000$ in figures 2.1 and 2.2 into a slightly concave kink in figure 2.3 due to the phase-out of the recapture tax under the EITC. By making the tax schedule less convex in this range, the EITC can potentially encourage extra risk-taking if outcomes in this range are more relevant for any given individual.

A second important complication is the payroll tax. The payroll tax adds both a new convex kink and a new concave kink to the overall tax schedule. Consider first the convex kink. Under the payroll tax, self-employment profits are taxable, but self-employment losses are 


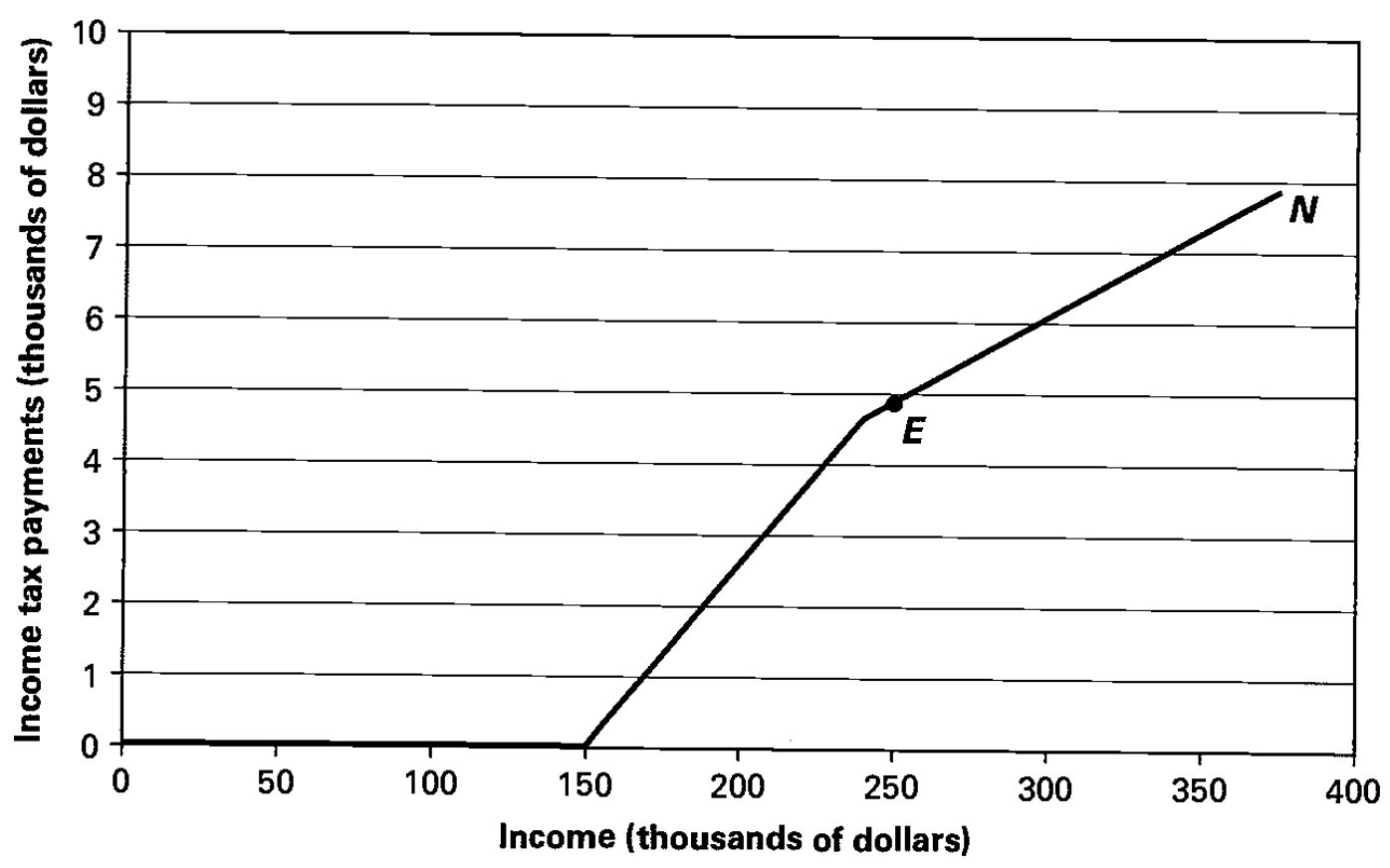

Figure 2.4

Tax Payments Under an Illustrative Payroll Tax

not tax deductible. With an effective payroll tax rate of 9.1 percent, taking on extra risk to increase both potential business profits and business losses by $\$ 100$ implies a drop in expected after-tax income of $\$ 4.55 .^{7}$

The concave kink occurs at the point where individuals earn the maximum income taxable under the Social Security and Disability Insurance (SSDI) components of the payroll tax (currently $\$ 90,000$ ). ${ }^{8}$ For an individual with expected earnings as an entrepreneur just equal to this amount, above-expected earnings are free of most payroll taxes, while the individual saves on payroll taxes to the extent that earnings are less than expected. This phase-out of the payroll tax therefore creates in itself a subsidy to risk-taking. Figure 2.4 graphs the payroll tax as a function of AGI in the above example and shows both new kinks.

A third important complication is the option the entrepreneur faces to check the box and pay taxes on this business income under the corporate tax rather than under the personal tax. When would this be attractive to do? The individual can make this choice ex post, knowing the taxable income that year, though must stick with this choice for at least five years. Based on tax incentives alone, entrepreneurs should find it attractive to check the box if the business has (and should continue to have) net profits, though they will normally prefer to remain noncorporate while the firm has net losses. Why is this? 
When the firm has profits, the key issue is the relative size of the personal tax rate versus the corporate tax rate on these profits. The initial bracket under the corporate tax is 15 percent, though this applies by statute to only the first $\$ 50,000$ of corporate profits. However, as described in detail in Sommerfeld and Jones (1991), a firm can be divided into multiple corporations, with each filing corporate taxes separately. If there are no real costs of doing this, as they argue is the case for reasonably small firms, then the corporate profits can all be subject to just this 15 percent corporate tax rate.

Corporate profits are also subject to further taxes when they are taken out of the firm as dividends or realized capital gains. We focus on capital gains realizations since this is the more tax efficient way to extract money from a corporation. The conventional estimate of the effective capital gains tax rate, coming from Feldstein, Dicks-Mireaux, and Poterba (1983), is one-quarter of the statutory tax rate, reflecting tax savings from deferral and write-up of basis at death. With a statutory capital-gains tax rate of 15 percent and a 50 percent exclusion of capital gains from small business stock held for at least five years (under IRC section 1202), this implies an effective capital gains tax rate of just $.25 \times .5 \times .15=.01875$ on the profits left net of the corporate tax. The overall tax rate on corporate profits is then $.15+.01875 \times .85 \approx$ .166 .

If the firm were instead to remain noncorporate, the marginal personal income tax rate on the income will be at least 15 percent in the above example if the individual's AGI is above $\$ 30,000$. Noncorporate profits are also subject to statutory payroll taxes at an effective tax rate of approximately 9.1 percent. $^{9}$ Given that half of payroll tax payments are deductible from taxable income under the personal income tax, the overall tax rate on noncorporate profits for an individual with AGI of at least $\$ 30,000$ is a minimum of $.15 \times(1-.5 \times .153)+.091=.23$. Clearly, almost all individuals do better by using the corporate tax schedule whenever the firm has profits.

What about when the firm has losses? If the firm remains noncorporate when it has losses, then these losses can be deducted against other personal income under the personal tax that year, reducing the entrepreneur's personal taxes immediately in proportion to her marginal tax rate. When losses are large enough to make net income negative, then these "net operating losses" can be carried back (or carried forward) and used to generate an immediate refund of taxes paid in 
another tax year in proportion to the marginal tax rate faced in that year. $^{10}$

For a corporation, in contrast, business losses can only be offset against profits earned in past or future years for that particular business. For entrepreneurial start-ups, there are no past profits and there is a reasonably high probability that the firm will not succeed, in which case it has no future profits either. Even when the firm does have future profits, the corporate taxes saved on tax-loss-carryforwards depends on the corporate marginal tax rate, which we argued above will likely be only 15 percent.

Current business losses, however, also reduce the capital gain or increase the capital loss for the entrepreneur on the equity the entrepreneur has in the firm. The resulting tax savings on reduced capital gains would be trivial, as argued above. However, IRC section 1244 allows capital losses on small business stock to be treated as ordinary losses under the personal income tax, regardless of holding period, and imposes much higher limits on the amount of losses that can be taken compared with other capital losses. ${ }^{11}$ If the capital loss simply equals the accumulated annual losses until the business is shut down, then the deduction for capital losses under the personal income tax is the same as would have occurred if the firm remained noncorporate, except that the deductions are deferred in time. ${ }^{12}$ Whether it is advantageous on tax grounds to be corporate or noncorporate if the firm has losses then depends on the probability the firm with current losses ultimately has a capital gain or a capital loss, and on the personal marginal tax rate the individual faces now on noncorporate losses compared with the expected marginal tax rate the individual would face in the future on realized capital losses (correcting for the loss due to deferral of these tax savings).

Regardless of all these complications, the option to be corporate or noncorporate in itself encourages more entrepreneurial risk-taking. Firms with profits will choose whichever form faces the lowest tax rate, while firms with losses will choose the form generating the greatest tax savings from these losses. To the extent that the option to incorporate reduces the tax rate on profits or increases the tax savings on losses, risk-taking is encouraged.

Figure 2.5 captures the tax implications of the option the firm has to incorporate. Here, we assume the same progressive tax schedule under the personal tax as used in figure 2.2, but now we allow the firm to 


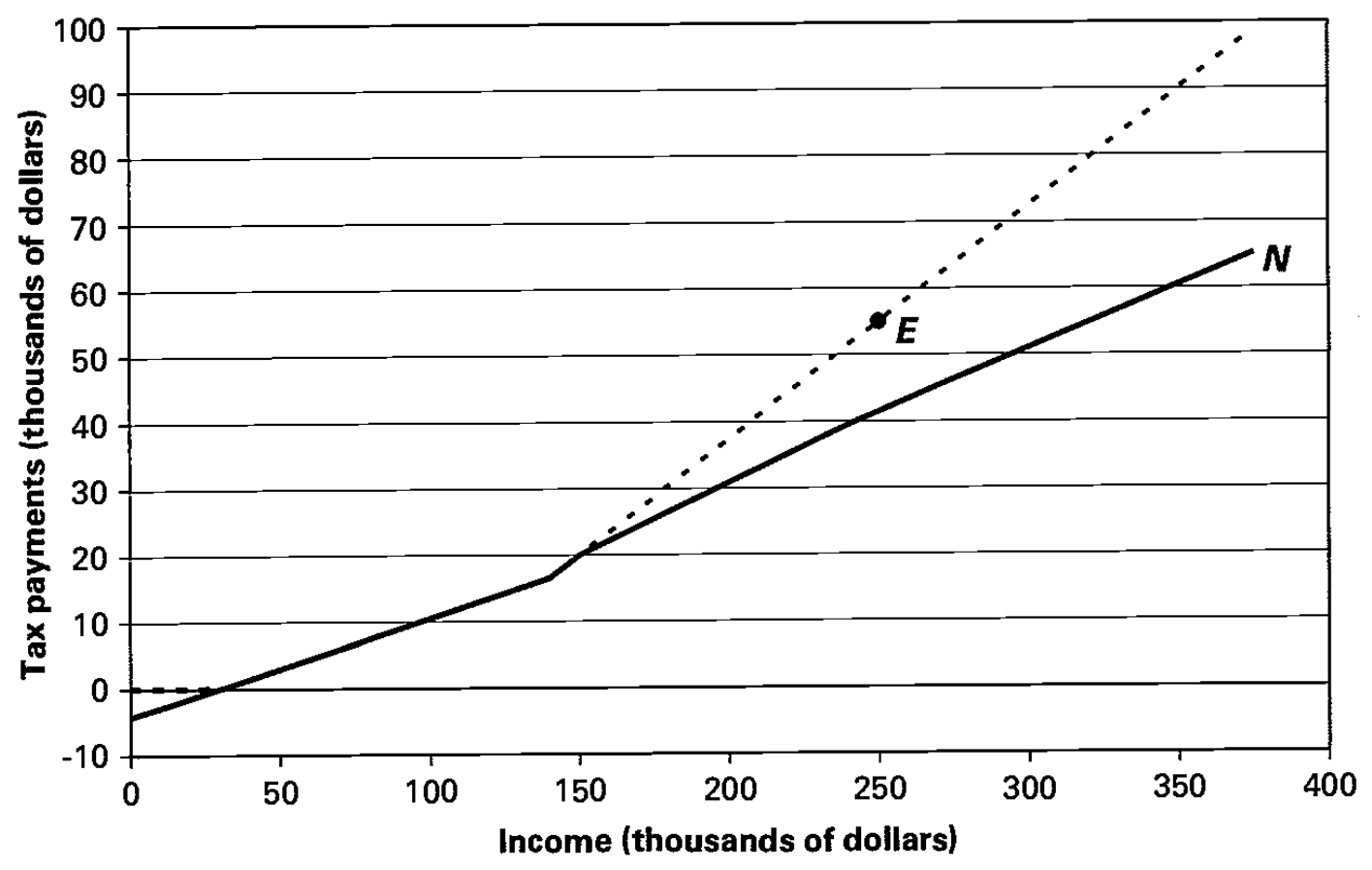

Figure 2.5

Effects of Checking the Box

incorporate whenever it is advantageous on tax grounds. As described above, incorporation is advantageous whenever the firm has profits, which occurs in our example for AGIs above $\$ 150,000$. In our example, the firm will also choose to incorporate when it would otherwise be in a zero personal tax bracket since then the ability to deduct capital losses on the corporate equity from personal taxable income provides at least some tax savings. Comparing figure 2.5 with figure 2.2, we find that the effective tax schedule has become less convex, so that the option to check the box encourages entrepreneurial risk-taking.

Note that this option to check the box can make being an entrepreneur more attractive than being an employee even if the firm has no risk. An employee would end up at point $E$ in figure 2.5 since wages and salaries are necessarily taxed under the personal income tax. Business income in contrast can be taxed as corporate income if the individual chooses to check the box. When the effective tax rate on corporate income is below the relevant personal tax rate, as is true in this example, then this option to incorporate encourages entrepreneurial activity even for a firm facing no risk. As a result, there are separate tax incentives affecting whether to be self-employed and then, if an individual is self-employed, how risky a project to pursue. 


\subsection{Net Sharing of Risks with the Government}

When the entrepreneur is risk-averse, the tax law can potentially provide a further encouragement to entrepreneurial activity by sharing the resulting risks with the government.

In order to characterize the behavior of a risk-averse individual, assume that the potential entrepreneur has constant relative risk aversion and maximizes $E U(Y)=E \ln Y .{ }^{13}$ Given this degree of risk aversion and if we ignore taxes, an individual would be indifferent between being an employee earning $\$ 100,000$, with outside income of $\$ 150,000$, and being an entrepreneur if the potential payoffs from being an entrepreneur are equally likely to be either $\$ 300,000$ or $-\$ 11,100$.

How would taxes affect this choice? If we impose a flat tax rate of 25 percent on all income, with no exemptions or deductions, then behavior does not change. This is a consequence of our assumption here that the utility function has constant relative risk aversion. With a flat tax rate of 25 percent on all income above an exempt amount of $\$ 30,000$, in contrast, being an entrepreneur becomes slightly more attractive. The individual would now be indifferent if the payoffs from being an entrepreneur were either $\$ 300,000$ or $-\$ 13,000$ pretax.

Now, shifting to a progressive tax structure can easily generate yet more entrepreneurial activity. For example, when the tax rate instead is 15 percent on income between $\$ 30,000$ and $\$ 140,000$, and 35 percent on any further income, the after-tax income of an employee earning $\$ 100,000$ with $\$ 150,000$ of outside income is unaffected. However, for an entrepreneur, after-tax income when the firm does badly is higher than when the individual faces a flat 25 percent tax rate. Though aftertax income when the firm does well is much lower under this progressive schedule, raising net-of-tax income when the individual is badly off is more important to a risk-averse individual than an offsetting reduction in income when the firm succeeds. With the assumed degree of risk-aversion, the individual would be indifferent to becoming an entrepreneur if the payoffs from being an entrepreneur were either $\$ 300,000$ or $-\$ 17,800$ pretax. As a result, more people will choose to become entrepreneurs under this progressive tax structure than under the proportional tax structure, and those who do become entrepreneurs would choose to take on more risk.

To see more formally why shifting to a progressive rate schedule can encourage entrepreneurial risk-taking, compare the utility of the entrepreneur under the two tax systems: $E U\left(\tilde{Y}\left(1-t_{f}(\tilde{Y})\right)\right)$ and $E U(\tilde{Y}(1-$ 


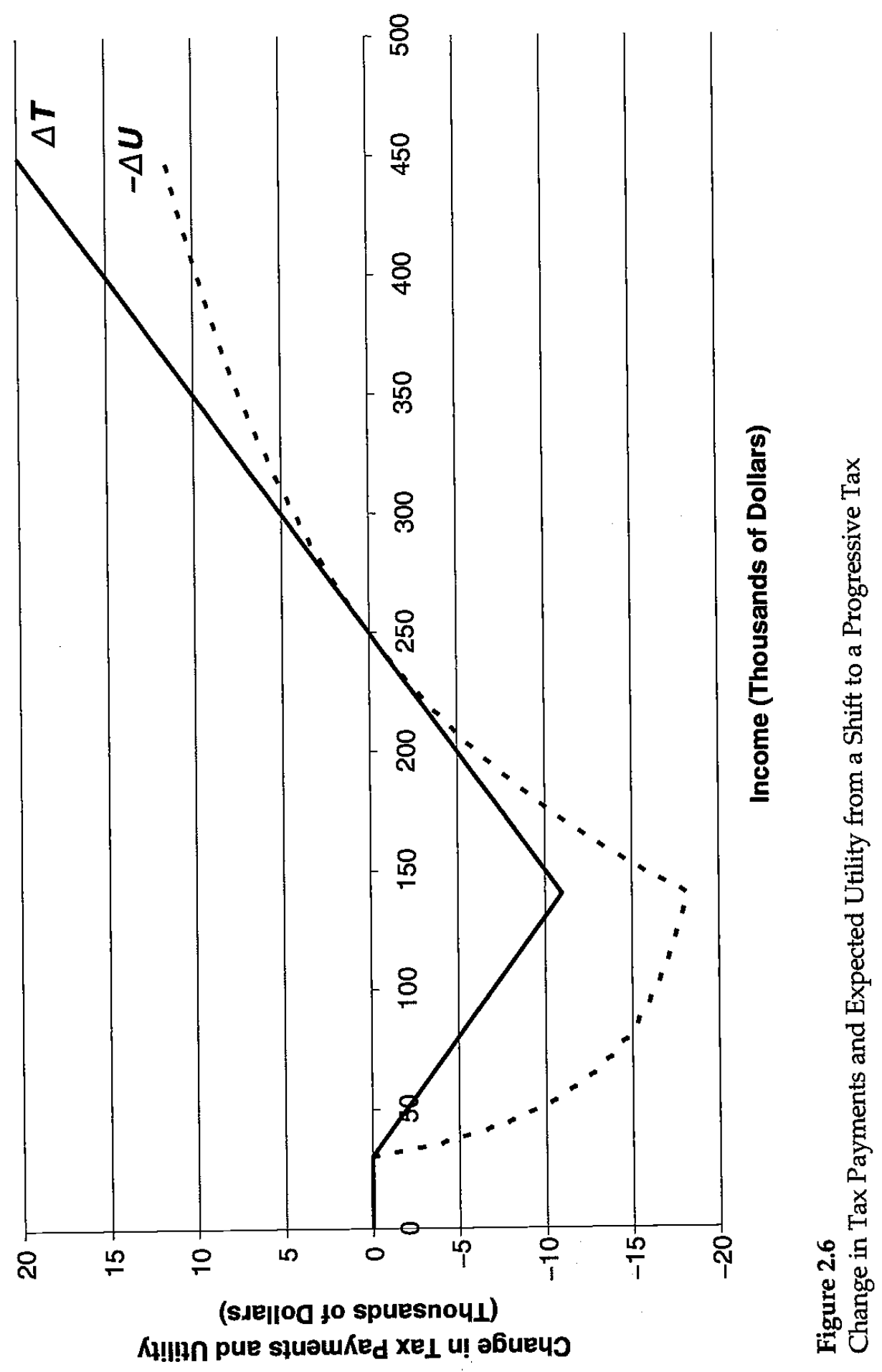


$t(\tilde{Y})))$, where $t_{f}(\tilde{Y})$ describes tax payments under a flat tax on all income above an exempt amount, while $t(\tilde{Y})$ describes a nonlinear tax schedule on all income above this same exempt amount. Using a firstorder Taylor approximation, expected utility under the nonlinear tax structure can be approximated by:

$$
E U(\tilde{Y}(1-\tilde{t})) \approx E U\left(\tilde{Y}\left(1-\tilde{t}_{f}\right)\right)-E\left[\left(\tilde{t}-\tilde{t}_{f}\right) \tilde{Y} U^{\prime}\left(\tilde{Y}\left(1-\tilde{t}_{f}\right)\right)\right]
$$

Whether a progressive tax encourages or discourages entrepreneurial risk-taking, compared with a flat tax, depends on the sign of the second term in equation (2.1). This term is a weighted sum of the changes in tax payments across income realizations, where the weights are given by the associated marginal utilities of income $\left(U^{\prime}\right)$. Since $U^{\prime}$ is a declining function of net-of-tax income, the tax savings at lower income levels under a progressive rate structure receive more weight, whereas the extra tax payments at higher income levels receive less weight. For a risk-averse individual, this greater weight on tax savings than on tax surcharges can easily make entrepreneurial risk-taking more attractive under a progressive tax than under a proportional tax.

Figure 2.6 graphs these tradeoffs. We first graph the change in overall tax payments at each income level (labeled $\Delta T$ ) arising from the use of a progressive rather than a proportional tax: $\left(\tilde{t}-\tilde{t}_{f}\right) \tilde{Y}$. With a progressive schedule, the entrepreneur pays less taxes when the firm does badly and more taxes when the firm does well. As before, expected tax payments are higher under a progressive tax. We then graph the loss in utility, denoted $-\Delta U$, arising from use of a progressive tax under our previous assumption that $U(Y)=\ln (Y)$. The tax savings under a progressive rate schedule if the firm does badly now receive much more weight relative to the potential tax surtaxes if the firm does well. The expected utility loss can easily be negative, so that utility from entrepreneurship is higher under a progressive rate schedule than under a flat tax.

\subsection{Tax Evasion}

One omission from the preceding discussion is the greater ease of tax evasion on business income than on wage and salary income. Andreoni et al. (1998), quoting statistics from past Tax Compliance and Measurement Program (TCMP) audits in the United States, reports estimates of evasion rates among sole proprietorships ranging from 16 percent to 39 percent, depending on industry, with the highest evasion rates in retail trade and the lowest rates in wholesale trade, fishing, 
agriculture, real estate, and finance. ${ }^{14}$ This greater ease of tax evasion certainly makes self-employment per se more attractive. Yet greater opportunities for tax evasion can easily reduce the amount of risktaking among those who do become entrepreneurs, implying ambiguous net effects on overall entrepreneurial risk-taking.

Why might this be the case? We expect that individuals will take advantage of any opportunities to avoid tax ex post whenever the probability of being caught and the resulting fines are low enough. Such evasion means that net-of-tax incomes become more risky ex ante. Subsidies to risk-taking and risk-sharing with the government both become less important. For both of these reasons, the optimal amount of risk-taking can drop when evasion is easier, even though the utility of the entrepreneur is certainly higher. So, though more people may become self-employed due to the greater opportunities to evade taxes on business than on wage income, those who choose selfemployment are likely to choose less risky projects. Given the ambiguity of the role of tax evasion, this is the one effect described above that we do not account for explicitly in the empirical work reported on below.

\section{Empirical Evidence on the Net Effects of Taxes on Entrepreneurial Activity}

The above discussion lays out the range of complications in the tax law that potentially affects entrepreneurial risk-taking. This discussion, however, provides no information about the quantitative importance of any particular provision in the tax code for the incentives to engage in entrepreneurial risk-taking. To judge this, we must turn to the data. In doing so, we draw heavily on our past work, reported in Cullen and Gordon (2005).

\subsection{Evidence Based on Past Data and Tax Law}

In Cullen and Gordon (2005), we begin by deriving an expression capturing the overall effect of the tax structure on entrepreneurial risktaking, capturing each of the effects described above. In particular, we start with an explicit measure of individual utility and calculate the optimal extent of entrepreneurial risk-taking for each individual given the range of possible outcomes that could result and the resulting tax treatment for each possible outcome. Individual choices include whether to become self-employed; if so, the size of the business (own labor input, 
number of employees, and capital investment); and then the riskiness of that business. In capturing tax incentives, the paper takes account of the progressivity of the personal tax schedule, complications in the personal tax law such as the EITC, the tax treatment of "net operating losses," the specific treatment of capital gains on small business stock, the choice whether to incorporate some or all of the firm's activities, and the effects of the payroll tax if the firm remains noncorporate.

The resulting expression for tax incentives depends on several behavioral parameters, in addition to characteristics of the tax law. For one, the degree of risk aversion matters since this affects the importance of any risk-sharing with the government. In addition, the typical degree of riskiness of a start-up firm relative to an entrepreneur's overall income matters. The importance of risk considerations relative to the tax savings that occur with a new business even without risk also needs to be inferred from the data.

The next step in jointly estimating these parameters determining effective tax incentives along with the degree of responsiveness of entrepreneurial risk-taking to tax incentives is to construct a measure of entrepreneurial risk-taking. Our perception was that the ideal would be a measure of the riskiness of the individual's business activity relative to that individual's earnings ability. The extent of an individual's risk-taking is inherently unobservable, however, depending on ex ante assessments. All we can potentially observe is ex post outcomes. We chose to focus on a simple indicator for the extent of entrepreneurial risk-taking equal to a dummy variable measuring whether or not the individual reported noncorporate losses exceeding 10 percent of reported wage and salary income. ${ }^{15}$ While profits of any given size can arise even without risk, if the size of the firm is appropriate, losses should occur only if the firm has undertaken a risky project. ${ }^{16}$ The riskier the project or the larger the project for any given degree of riskiness, the higher is the individual's overall risk-taking relative to his or her earnings ability, and the higher is the probability of having ex post losses above any given fraction of their reported labor income.

In Cullen and Gordon (2005), we then estimate the various parameters involved in both the measurement of tax incentives and the responsiveness of individual behavior to these tax incentives to best explain variation in the extent of entrepreneurial risk-taking, using a data set consisting of individual tax returns for roughly 2 million single individuals spanning twenty-two years between 1964 and 1993.17 In estimating the responsiveness of behavior to tax incentives, we 
calculated the average tax incentives within various quantiles of the potential earnings distribution ${ }^{18}$ and then used this information to forecast the fraction within each quantile that reported large noncorporate losses. ${ }^{19}$ Using a difference-in-difference estimation strategy, we then examined how this fraction changes over time for one quantile relative to another compared with how relative tax incentives change; formally, we did this by including quantile and year dummies in the specification. The parameters affecting the measurement of tax incentives, and the responsiveness of behavior to these tax incentives, were then chosen to best explain the patterns observed in the data.

We restricted the study to single individuals because we had too little information about the choices made by married couples to calculate tax incentives properly. ${ }^{20}$ Our forecasted sensitivity of behavior to tax incentives as a result is based solely on the behavior of single individuals. Any inference about the behavior of married couples is speculative. If married couples are equally responsive to tax incentives as single individuals, and if the weighted average change in tax incentives is the same for single filers as for all tax payers, then our estimates for the percentage changes in entrepreneurial risk-taking would still be appropriate. We presume that married individuals tend to have higher earnings ability than single individuals, though. Since the change in tax incentives varies by earnings level, our forecasts below for individuals earning higher incomes should get more weight when forecasting effects for the population as a whole.

In presenting results based on our prior estimates, we first describe how the weighted average net tax incentives to engage in entrepreneurial risk-taking have varied over time for selected years between 1964 and $2001{ }^{21}$ Results are reported graphically in figure 2.7. In making sense of the patterns in this figure, it helps to step back to think through the role of different elements in the tax structure. As described above, all but the lowest ability entrepreneurs have an incentive to incorporate their business whenever it has profits but to remain noncorporate as long as the business has tax losses. Expected after-tax profits then increase to the extent that personal tax rates are high relative to corporate tax rates, since to that extent the entrepreneur has to bear a smaller fraction of the losses net of tax than she gets to keep of any profits. In addition, given risk-aversion, a higher overall marginal tax rate implies more risk-sharing with the government. Since the entrepreneur then has to bear less risk, the marginal cost of risk-bearing should be lower, thus encouraging more risk-taking. 


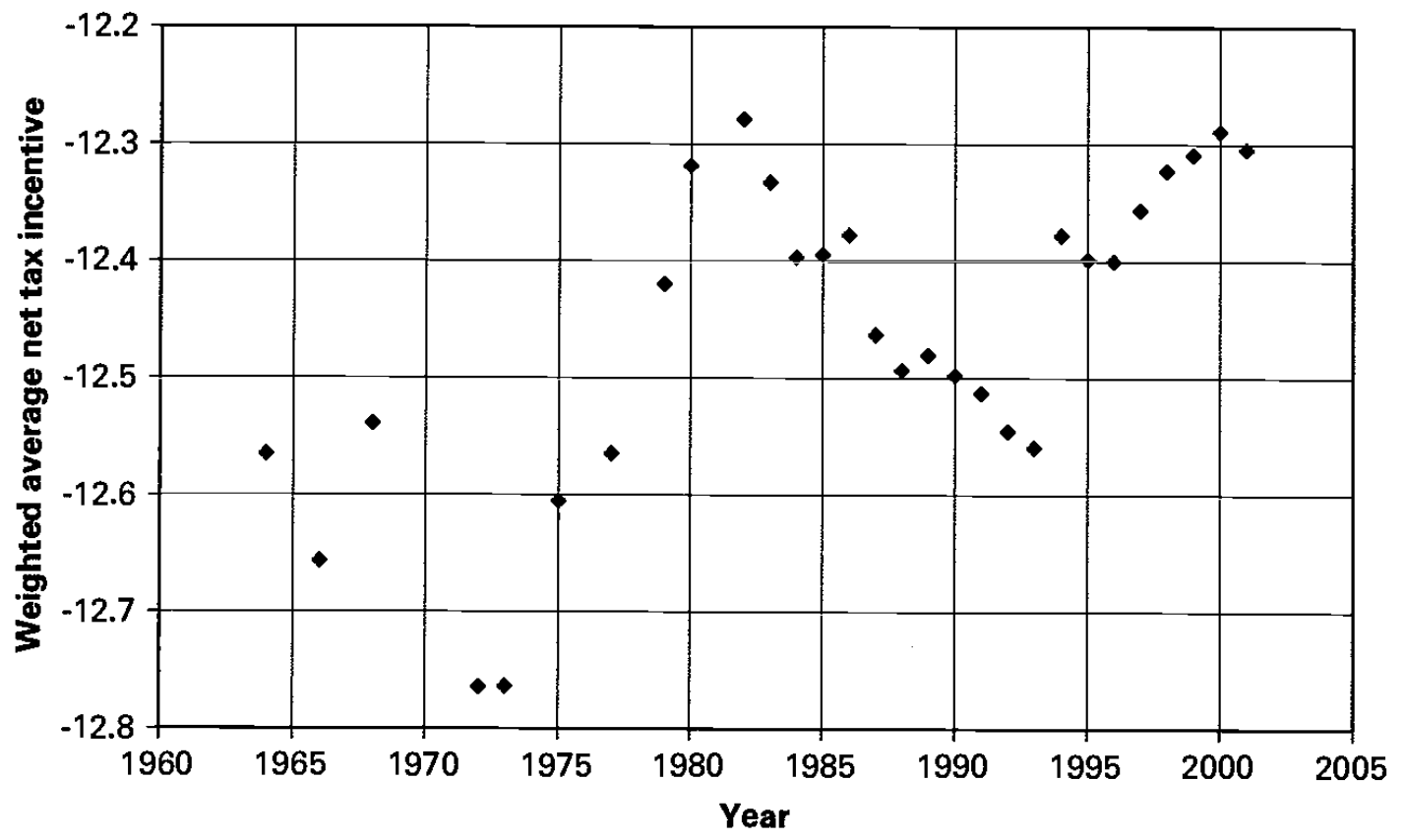

Figure 2.7

Weighted Average Net Tax Incentive by Year

The reported numbers in figure 2.7 reflect the interaction of many changing provisions in the tax code. For example, between 1968 and 1972 a key change discouraging entrepreneurial risk-taking was a general drop in marginal tax rates, implying less risk-sharing with the government. ${ }^{22}$ This effect was partially offset, though, by an increase in the payroll tax rate. During the rest of the 1970s, inflation caused bracket creep, pushing taxpayers into steadily higher personal tax brackets. With a higher personal tax rate, entrepreneurs bore a smaller fraction of any business losses, while business profits largely were taxed at the corporate rate and so were unaffected by this bracket creep. This bracket creep therefore encouraged more entrepreneurial risk-taking. The tax reforms during 1981-1983 introduced a series of cuts in personal, corporate, and capital gains tax rates. Such a drop in tax rates discourages risk-taking through reducing the sharing of risk with the government, and in particular cutting the sharing of losses with the government. With the 1986 tax reform, personal tax rates fell substantially relative to the effective tax rate on corporate income, particularly given the jump in the effective capital-gains tax rate. As a result, entrepreneurs bore yet more of their losses and could keep less of any profits, thus discouraging risk-taking. The other main change in tax incentives occurred in 1994. In this year, the capital gains tax rate on small business stock was cut in half, encouraging more risk-taking. 


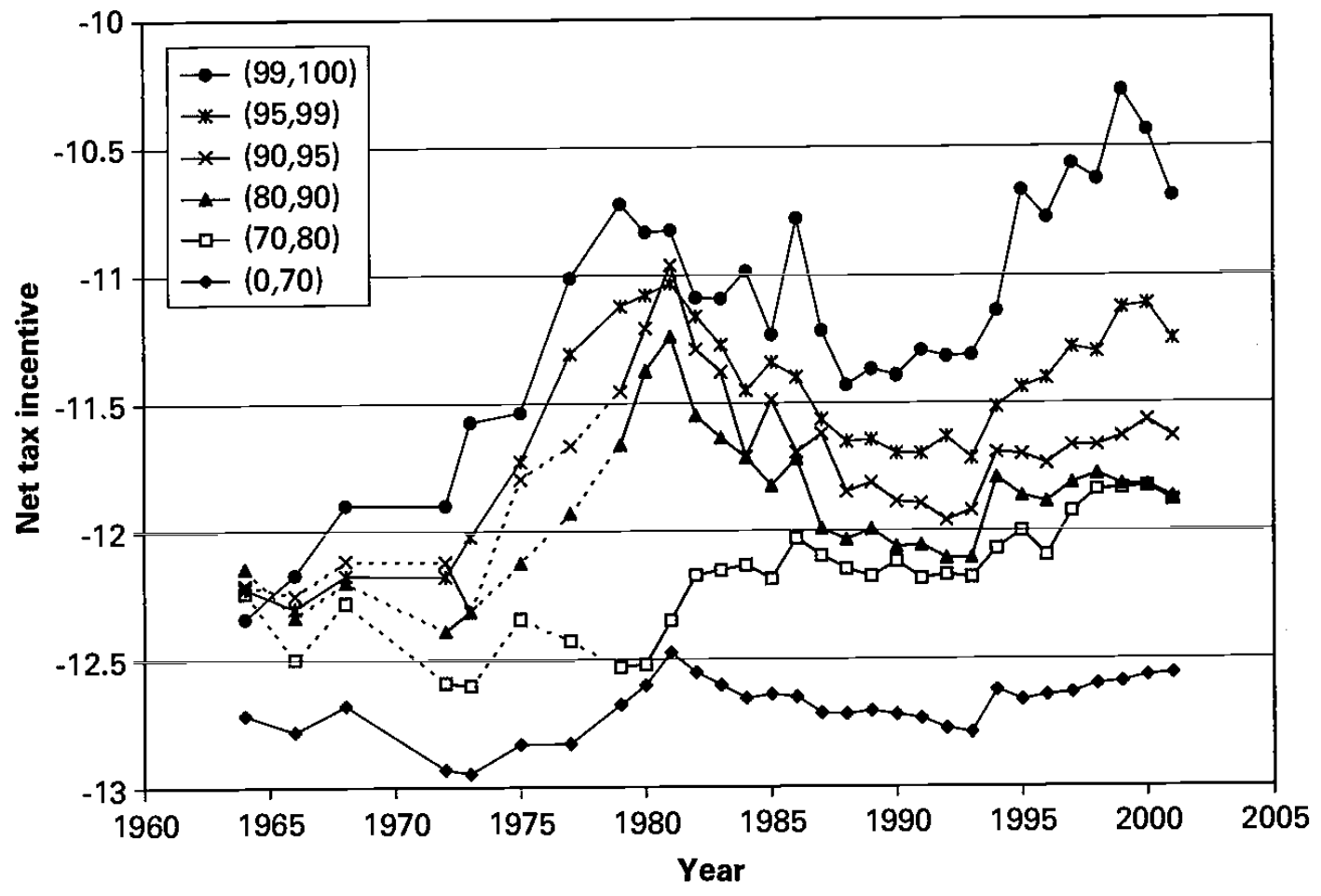

Figure 2.8

Net Tax Incentive by Potential Earnings Quantiles

The earnings limit for the Medicare payroll tax was eliminated in this year, penalizing wage and salary income relative to corporate business income. In addition, the EITC program was expanded dramatically, encouraging risk-taking for those eligible for the program primarily when their firm has losses.

Figure 2.7 focuses on aggregate incentives only. This hides substantial heterogeneity within the population in the incentives faced. In figure 2.8, we graph how average tax incentives varied across different potential earnings quantiles over this same time period. ${ }^{23}$ Here, we find that tax incentives to engage in entrepreneurial risk-taking are almost always higher when a person's earnings ability is higher. Since profits are taxed largely at the same corporate tax rate, regardless of quantile, those in higher tax brackets gain by having to absorb a smaller fraction of any business losses. Tax incentives are also more volatile for those in the top tax brackets. Tax incentives do not move in parallel across earnings levels; in fact this is the source of identification in our estimation procedure.

How important are these tax incentives for behavior? Figure 2.9 graphs the actual data on the fraction within each quantile that reports large entrepreneurial losses. Comparing figure 2.8 with figure 2.9 


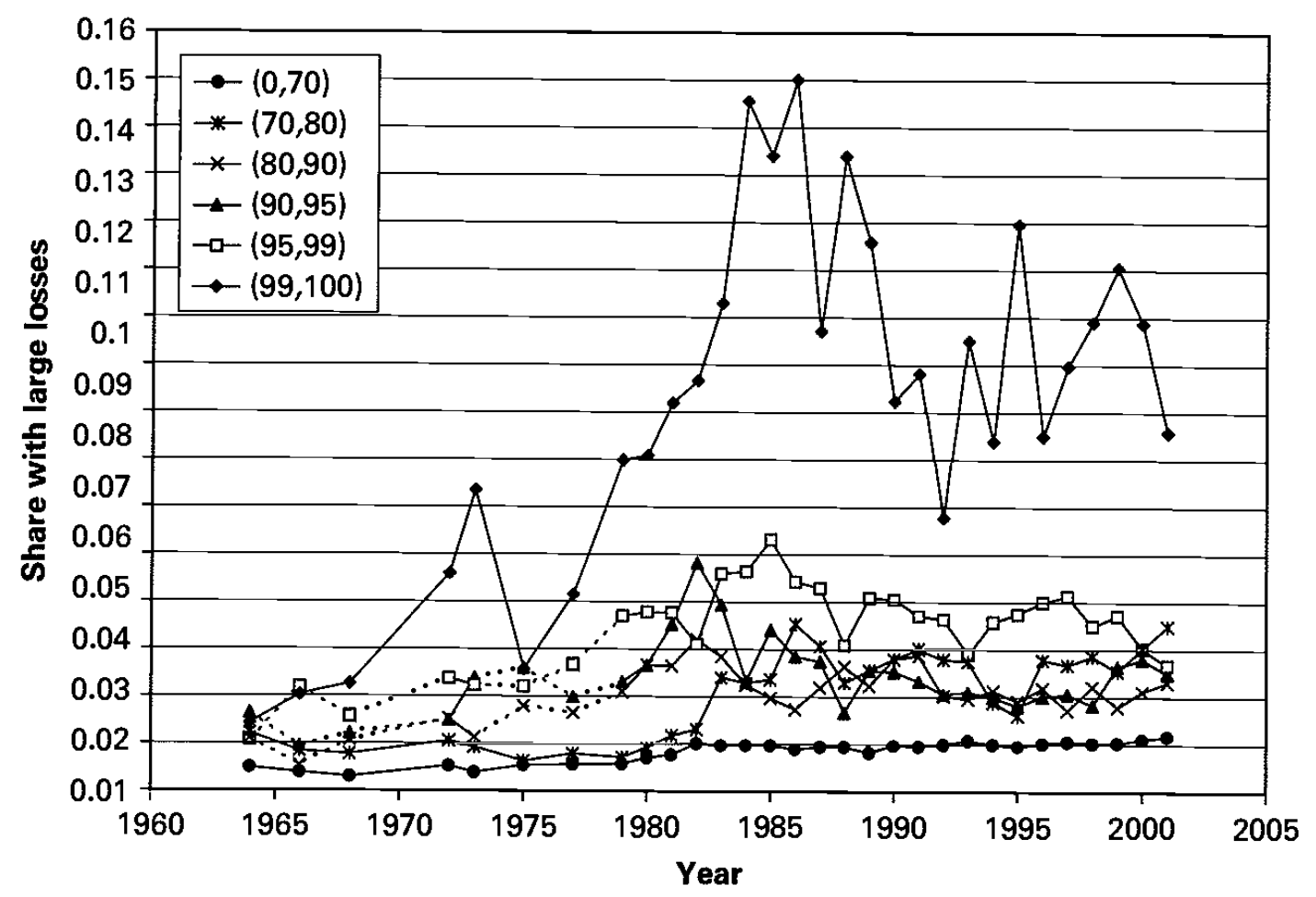

Figure 2.9

Loss Rates by Ability Quantile

shows that tax incentives and behavior appear to be closely linked across ability groups, and there are some striking shared movements across years. Our estimates are not based on the overall correlation, however, but instead depend on differing changes in behavior across quantiles as a function of differing changes in tax incentives. Focusing on this more subtle and useful source of variation, we find strong links between taxes and risk-taking. We see this in the results reported next, simulating the behavioral responses to possible tax reforms.

\subsection{Forecasts Based on Possible Future Tax Laws}

We now turn to simulating the effects of possible tax reforms on the extent of entrepreneurial risk-taking. The latest year of data we have for actual behavior is 2001 . We chose to use these data as our benchmark, simulating how behavior in 2001 would have differed had the tax law been different in 2001.

Row (1) of table 2.1 reports data on the fraction of taxpayers within each potential earnings quantile predicted to have large entrepreneurial losses in 2001, given the 2001 sample of non-joint returns and the 2001 tax code. ${ }^{24}$ Since entrepreneurial risk-taking is heavily concentrated among the highest earning ability individuals, we again define 
Table 2.1

Forecasted Rates of Active Losses

\begin{tabular}{|c|c|c|c|c|c|c|c|c|}
\hline & \multirow[b]{2}{*}{ Tax Provisions } & \multicolumn{6}{|c|}{ Potential Earnings Quantile } & \multirow{2}{*}{$\begin{array}{l}\text { Aggre- } \\
\text { gate }\end{array}$} \\
\hline & & $(0,70)$ & $(70,80)$ & $(80,90)$ & $(90,95)$ & $(95,99)$ & $(99,100)$ & \\
\hline \multicolumn{9}{|c|}{ Actual tax law } \\
\hline (1) & 2001 tax law & 0.010 & 0.023 & 0.020 & 0.022 & 0.044 & 0.124 & 0.023 \\
\hline (2) & 2005 tax law & 0.008 & 0.018 & 0.016 & 0.018 & 0.035 & 0.094 & 0.018 \\
\hline \multicolumn{9}{|c|}{ Successive reforms } \\
\hline (3) & $\begin{array}{l}\text { Removing taxation } \\
\text { of financial income }\end{array}$ & 0.008 & 0.017 & 0.017 & 0.019 & 0.032 & 0.066 & 0.016 \\
\hline (4) & $\begin{array}{l}\text { Removing special } \\
\text { treatment of small } \\
\text { business capital } \\
\text { gains }\end{array}$ & 0.006 & 0.013 & 0.012 & 0.013 & 0.022 & 0.046 & 0.012 \\
\hline (5) & $\begin{array}{l}\text { Flat personal tax } \\
\text { rate }(19 \%)\end{array}$ & 0.009 & 0.020 & 0.018 & 0.017 & 0.024 & 0.038 & 0.015 \\
\hline (6) & $\begin{array}{l}\text { Setting the } \\
\text { corporate income } \\
\text { tax rate to } 19 \%\end{array}$ & 0.008 & 0.016 & 0.015 & 0.014 & 0.020 & 0.031 & 0.013 \\
\hline (7) & $\begin{array}{l}\text { Disallowing carry } \\
\text { forward/backward } \\
\text { of net operating } \\
\text { losses }\end{array}$ & 0.005 & 0.010 & 0.010 & 0.009 & 0.013 & 0.020 & 0.008 \\
\hline (8) & Removing the EITC & 0.007 & 0.013 & 0.011 & 0.011 & 0.017 & 0.031 & 0.011 \\
\hline \multicolumn{9}{|c|}{ Successive reforms } \\
\hline (9) & $\begin{array}{l}\text { Flat personal tax } \\
\text { rate }(19 \%)\end{array}$ & 0.014 & 0.032 & 0.027 & 0.026 & 0.037 & 0.067 & 0.024 \\
\hline (10) & $\begin{array}{l}\text { Removing taxation } \\
\text { of financial income }\end{array}$ & 0.014 & 0.029 & 0.027 & 0.025 & 0.035 & 0.049 & 0.022 \\
\hline (11) & $\begin{array}{l}\text { Setting the } \\
\text { corporate income } \\
\text { tax rate to } 19 \%\end{array}$ & 0.011 & 0.024 & 0.022 & 0.020 & 0.028 & 0.041 & 0.018 \\
\hline
\end{tabular}

Notes: Each column shows the predicted rate of active business losses for the ability quantile indicated for our sample of non-joint taxpayers in 2001. The prediction equation is based on our prior estimation results, with the relevant tax incentives calculated under the tax provision indicated in each row. Each taxpayer is assigned to a potential earnings quantile based on predicted earnings as an employee, as described in note 18 in this paper. To calculate the aggregate rate shown in the final column, we weight the rate for each quantile by its share of overall predicted earnings. In the first row, the tax measures are calculated using the actual tax provision in place in 2001. The second row shows the predicted rates had the 2005 provisions (suitably adjusted for inflation) been in place. The remaining rows predict loss rates under various hypothetical reforms. 
the quantiles to focus on the behavior among those in this upper tail of the distribution of potential earnings. As seen in the table, the fraction reporting large losses in the top 1 percent of the earnings distribution is over twelve times as high as the overall fraction in the bottom 70 percent of the earnings distribution, and even almost three times as large as the fraction among the rest of the top 5 percent of the earnings distribution.

The starting point for tax reform, of course, is not the tax law as of 2001 but the tax law in place currently. Row (2) of table 2.1 simulates how these reported fractions would have differed had the 2005 law been in place in 2001. The forecast is that entrepreneurial risk-taking has fallen by over 14 percent due to the tax reforms between 2001 and 2005. One aspect of the reform, the cut in the capital gains tax rate, in itself should have increased the amount of entrepreneurial risk-taking. Since small businesses already face such a low effective capital gains tax rate due to IRC section 1202, however, the effects of this change on small business activity would be muted. In contrast, the drop in personal tax rates, holding corporate tax rates fixed, implies less sharing of losses with the government, making risk-taking more costly to an entrepreneur. Taxes on potential profits, in contrast, largely remain unaffected by the tax reforms since they should largely be subject to the unchanged corporate tax rate.

We then compare the forecasted rates of entrepreneurial risk-taking that would have occurred in 2001 under any particular proposal with those that we forecast would have prevailed in 2001 under the actual 2005 tax law. Since the president's tax reform commission has not yet submitted its recommendations, we can only speculate about the types of reform proposals that it will come up with. ${ }^{25}$

Our presumption is that these tax reform proposals will include sharp cuts in the taxes due on financial income from savings. The first tax reform we then simulate is one that eliminates any taxes on interest, dividend, and capital gains income, though we leave in place the deductibility of mortgage interest payments. The results are shown in row (3) of table 2.1. As with the tax reforms between 2001 and 2005, there should be two offsetting effects on entrepreneurial risk-taking. First, the elimination of any taxes on capital gains income in itself will encourage more entrepreneurial risk-taking, though this effect will be small since the effective capital gains tax rate is already very low. In addition, the drop in taxable income due to the exemption of financial income from savings will cause entrepreneurs to fall into a lower or 
zero personal tax bracket more quickly, for any degree of business risk. Facing lower potential personal tax rates, a smaller fraction of business losses will be shared with the government, making risk-taking more costly. As with the 2005 reforms, this latter effect dominates overallthe forecasted rate of entrepreneurial risk-taking falls by 11 percent relative to the 2005 benchmark. Note, however, that effects are not uniform across quantiles since the relative importance of these two offsetting effects differs substantially across taxpayers.

In the above simulation, even though capital gains were made tax exempt, we left in place a special provision (IRC section 1244) that allows owners of equity in small businesses to deduct any capital losses (up to $\$ 50,000$ per year for a single individual) as ordinary losses rather than capital losses. If this provision were repealed as well, ${ }^{26}$ eliminating the tax deductibility of capital losses on small business stock, then entrepreneurial risk-taking would certainly fall further. The estimated effects of repealing section 1244, in addition to repealing the taxation of other forms of financial income from savings, appear in row (4) of table 2.1. Overall entrepreneurial risk-taking is predicted to fall by a further 22 percent relative to the 2005 benchmark. This fall occurs roughly proportionately in all quantiles.

We presume that another likely proposal for tax reform is a shift to a flat tax rate. Here, we made an attempt to choose a flat tax rate that would leave overall tax revenue unaffected, ${ }^{27}$ otherwise leaving the tax base unchanged. ${ }^{28}$ The rate we found was 19 percent.

Shifting to such a flat tax rate implies an increase in marginal tax rates for lower-earning individuals, and a drop in marginal tax rates particularly for the highest-earning individuals. As a result, lower earners who become entrepreneurs need to absorb a smaller fraction of any losses from their businesses, but higher-ability entrepreneurs have to absorb a larger fraction. Consistent with this, forecasted entrepreneurial risk-taking goes up among all quantiles other than the very top one, for an overall increase in risk-taking of 17 percent, judged from the 2005 benchmark.

A flat rate structure under the personal tax still leaves a difference in tax rates between noncorporate and corporate businesses. We next simulate the impact on entrepreneurial activity of increasing the corporate tax rate on small businesses from 15 percent to the presumed flat tax rate of 19 percent. By increasing the tax rate on business profits while leaving unaffected the tax rate on (noncorporate) business losses, risk-taking should be discouraged. Forecasted risk-taking in fact drops 
among all quantiles, for an overall drop of 11 percent relative to the 2005 benchmark.

One other likely objective of tax reform is tax simplification. The tax law includes a huge number of special provisions affecting virtually all aspects of the economy. With a major tax reform, one aim could be a wholesale repeal of these special provisions in order to generate a simpler and more transparent tax code. One provision of particular importance for noncorporate businesses is IRC section 172, which allows a carryback or carryforward of net operating losses into other tax years. ${ }^{29} \mathrm{~A}$ parallel provision, allowing income averaging, was repealed with the 1986 reform. What would be the implications for entrepreneurial risk-taking if section 172 were repealed in the process of tax simplification? With such a restriction on the deductibility of large business losses, risk-taking would clearly be discouraged. The forecasted effects are reported in row (7) of table 2.1. Here, we start from the tax provisions in row (6). The figures show a sizeable drop in risktaking in all quantiles, for a further overall drop of 28 percent relative to the 2005 benchmark.

Note that the tax law simulated in row (7) should largely correspond to the flat tax proposed in Hall and Rabushka (1995), with all income (corporate and noncorporate) above an exempt amount subject to one tax rate, with other tax provisions complicating the current tax law (including sections 172 and 1244 that specifically affect risk-taking in small businesses) repealed. Therefore, our forecast is that such a fundamental tax reform would reduce entrepreneurial activity by over half.

One further change that in principle could occur through fundamental tax reform is a repeal of the EITC. Certainly, if the flat tax were implemented through a tax just at the firm level, with no remaining personal tax filing, then the EITC would be difficult to maintain. Row (8) simulates the impact of such a repeal, starting with the tax system in row (7). Here, we find that entrepreneurial activity increases for all groups, implying that the EITC discourages entrepreneurial risktaking, at least starting from a Hall-Rabushka flat tax. ${ }^{30}$

Among the various tax reforms we have considered, the key reform that in itself resulted in an increase in forecasted entrepreneurial activity is the shift to a flat tax rate under the personal income tax. What would happen if this were the only change implemented? Results appear in row (9) of table 2.1. With a flat tax, marginal tax rates go up for lower-income taxpayers, providing more sharing of business losses with the government. In contrast, marginal tax rates fall sharply for 
those with the highest earnings. Consistent with this, we forecast an increase in entrepreneurial risk-taking among those in all but the highest ability group, for an overall increase in risk-taking by one-third.

Starting from a flat tax, if we then eliminated any taxes on interest, dividends, or capital gains, entrepreneurial activity again falls, and almost entirely among the highest ability group, as seen in row (10) of table 2.1. While the drop in taxable personal income cannot affect an entrepreneur's marginal tax rate as long as she continues to have positive taxable income, the probability of being in a zero tax bracket increases. Again, there is less risk-sharing with the government. This reform affects primarily the top quantile simply because the financial income from assets is much larger relative to potential labor income in this quantile.

If we then proceeded as before to tax corporate income at this same flat personal tax rate, forecasted entrepreneurial risk-taking again falls, as seen in row (11) of table 2.1, to a point effectively equal to that under current law. On net, as seen comparing row (11) with row (2), shifting from current law to such a Hall-Rabushka flat tax, being careful to leave in place the special provisions encouraging entrepreneurial activity, has no net effect on overall entrepreneurial activity. However, such a tax change reduces sharply the amount of entrepreneurial risk-taking by the highest ability taxpayers, while encouraging more such risktaking by the rest of the population.

Recall, however, that all of these figures reflect forecasts for entrepreneurial risk-taking among single individuals. Married individuals tend to be in higher tax brackets than single individuals. Assuming they are as responsive to tax incentives as single individuals, and that their tax incentives change to the same extent controlling for their initial tax bracket, we can forecast changes for the overall economy given these figures by putting more weight on changes in the higher tax brackets. ${ }^{31}$ As a result, we forecast some fall in entrepreneurial activity from fundamental tax reform, even under the optimistic assumption that the special provisions that encourage entrepreneurial risk-taking (IRC sections 172 and 1244) remain in place.

\section{Summary}

Fundamental tax reform necessarily will generate complicated and farreaching changes in the U.S. economy. We focus on only one: entrepre- 
neurial risk-taking. To what degree would plausible directions for tax reform induce an increase in entrepreneurial activity?

The findings are discouraging. Under the most dramatic change considered, a shift to a Hall-Rabushka flat tax ${ }^{32}$ forecasted entrepreneurial activity falls by half.

The devil is in the details, however. Two special provisions under the current tax code (IRC sections 172 and 1244) are forecasted to have large effects on entrepreneurial risk-taking. Section 172 allows "net operating losses" in a noncorporate firm to be carried back or carried forward into other tax years. Section 1244 allows realized capital losses on shares in a small business to be deducted as ordinary rather than capital losses (up to $\$ 50,000$ per year for a single individual). The above forecast assumes that both provisions would be repealed in the process of fundamental tax reform. If these provisions were left in place in the process of adopting a Hall-Rabushka flat tax, for example, then we forecast that overall entrepreneurial activity would remain effectively unchanged.

These are two small sections in the Internal Revenue Code among many others that could well disappear in the process of fundamental tax reform. We therefore close on a note of caution. The current complications in the law developed over many years, each in response to particular economic (and political) pressures. The result, of course, is a very complicated tax code, encouraging discussion of an abandonment of the existing income tax and replacing it with an entirely different tax structure. In the process, tax reform discussion focuses on the most basic aspects of the tax code, particularly the overall rate structure, and pays much less attention to these countless details in the tax code. Yet these details may have large economic effects that need to be given careful thought during discussion of fundamental tax reform. Certainly these two detailed provisions in the tax code appear to be the dominant consideration when forecasting the effects of fundamental tax reform on entrepreneurial risk-taking.

\section{Notes}

This paper was written for the NBER Conference on Tax Policy and the Economy, held in Washington, D.C., on September 15, 2005.

1. As an example, Sony was the key initial innovator in creating the video-cassette recorder, yet the market was ultimately captured by those using an imitating (VHS) technology. As another example, the Star desktop computer invented by Xerox included 
many of the key innovations still in use in PCs. Yet Apple, then IBM, and later other imitators captured the market for PCs instead.

2. Of course, the profits received by the initial entrepreneur may in part be at the expense of reduced profits going to a prior entrepreneur, imposing negative externalities. We presume in this discussion that the positive externalities from entrepreneurial activity far outweigh these negative spillovers.

3. Lemons problems can be particularly severe for entrepreneurial firms, given that the value of the firm is heavily dependent on the likelihood, timing, and quality of a possible innovation, information that would be particularly hard for an outside investor to monitor.

4. Existing firms may still be effective at taking the innovative ideas produced within start-up firms and then manufacturing and marketing the resulting products. These later stages in the process are not the likely sources of any externalities, however.

5. Tax structures that encourage risk-taking encourage all forms of risk-taking, and not just those that generate important externalities to other firms and to customers of the firm, so that they are not finely targeted on entrepreneurial activity. However, entrepreneurial activity certainly generates risks and so would be encouraged by any tax structure that encourages risk-taking in start-up firms.

6. Gentry and Hubbard (2004) focus on the effects of such progressivity in the personal tax schedule by comparing the expected marginal tax rate an entrepreneur would face at particular outcomes for profits versus losses, assuming risk-neutrality. The analysis we describe below includes many other features of the tax code, including the choice whether or not to incorporate, distortions created by the payroll tax, a variety of additional complications in the personal tax law such as the earned income tax credit and the treatment of "net operating losses," as well as possible risk aversion.

7. The effective payroll tax is lower than the statutory rate since additional taxes paid are partly offset by higher future Social Security benefits due to the extra covered earnings. Diamond and Gruber (1997) find that the present value of extra benefits should offset roughly half of the extra payroll taxes due. Applying this finding, we set the effective payroll tax rate to one-half the 12.4 percent statutory rate used to finance Social Security and Disability Insurance, plus the 2.9 percent statutory Medicare rate.

8. The payroll tax used for Medicare is not subject to an earnings ceiling and does not phase out.

9. We continue to follow Diamond and Gruber (1997) in assuming that half of the (nonMedicare) payroll taxes due on extra income are offset by extra future benefits.

10. By statute, "net operating losses" are losses in excess of positive wage and capital income net of standard/itemized deductions.

11. Under current tax law, a couple can convert $\$ 100,000$ in capital losses on small business stock into ordinary losses in each tax year.

12. The individual's marginal tax rate can also change over time, however, for example, if the individual realizes the capital loss after returning to being an employee.

13. This utility function in fact embodies less risk aversion than existing evidence suggests is plausible. See Barsky et al. (1997) for further discussion. 
14. A natural explanation for these differences in evasion rates among industries is the greater potential for cross-checking of claimed items when transactions occur with another firm than when they occur with an individual. The firm with a potential tax deduction arising from a transaction has an incentive to report it, giving the IRS an independent source of information about this source of taxable income of the seller. There is no such independent source of information for sales to individual customers.

15. Specifically, we defined noncorporate losses to be those reported on Schedule C or on Schedule $\mathrm{E}$ as either partnership losses or subchapter $\mathrm{S}$ corporate losses.

16. This is not entirely true. A riskless firm can still have losses in initial years and profits later. Such firms would be picked up by our indicator of entrepreneurial risk-taking if the initial losses are large enough.

17. For this current paper, we brought in comparable tax return data for another eight years (through 2001). We reestimated the responsiveness of behavior to tax incentives in this expanded sample and found similar results. However, given the complexity (nonlinear estimation on a huge sample), we did not attempt to reestimate the parameters (such as the degree of risk aversion) involved in the measurement of tax incentives. We therefore use our original estimates in the simulations reported below.

18. In order to use a consistent measure of potential earnings for each individual, regardless of whether the individual was self-employed, we forecast the labor income an individual would earn as an employee based on other information reported on the tax return-principally demographic information, income from financial assets, and certain itemized deductions (if present).

19. Specifically, we assumed a logit specification. If $P_{i t}$ denotes the fraction of quantile $i$ in year $t$ that has large losses, then a logit specification implies that $\ln \left(P_{i t} /\left(1-P_{i t}\right)\right)=$ $f\left(\mathbf{X}_{i t}, \beta\right)+\varepsilon_{i t}$, where $\mathbf{X}_{i t}$ includes tax incentives and various control variables, and $\beta$ is a vector of parameters to be estimated. Given the complicated ways in which risk affects tax incentives, there are unavoidable nonlinearities in the function $f($.$) .$

20. Both tax incentives and the nontax proclivity to engage in entrepreneurial risk-taking depend on an individual's earnings level. Yet we observe only a couple's combined wage and salary income and combined self-employment income.

21. The latest year in which a random sample of tax returns is now available is 2001 . We weight the tax incentives faced by any quantile by their potential earnings (defined as described in note 19).

22. In particular, the maximum tax rate on labor income fell from 75.3 percent to 50 percent, while the corporate tax rate fell from 24.2 percent to 22 percent. The maximum capital-gains tax rate also increased, raising the tax rate on profits while not affecting the tax rate on losses.

23. Since entrepreneurial activity is heavily concentrated among the highest earning individuals, we focus more heavily on the incentives faced at the upper end of the earnings distribution. The six series graphed represent the following percentile ranges of the potential earnings distribution: ( 0 percent-70 percent), ( 70 percent- 80 percent), ( 80 percent-90 percent), (90 percent-95 percent), (95 percent-99 percent), and (99 percent100 percent). See note 19 for information about the definition of potential earnings.

24. The reported fraction of tax payers with large entrepreneurial losses certainly understates the fraction of taxpayers engaged in entrepreneurial risk-taking since the figures 
include only those with large ex post losses. Given our estimate for the riskiness of entrepreneurial activity, roughly 30 percent of businesses should have tax losses, while fewer will have losses exceeding 10 percent of reported wage and salary income. The fraction of the population taking large entrepreneurial risks therefore exceeds $1 / .3$ times the fraction with large ex post losses.

25. One item on the reform agenda we did not focus on is the alternative minimum tax (AMT). As of 2001, very few people faced the AMT, so it would be of little importance using data from 2001 as a benchmark.

26. Section 1244 is one of the detailed provisions listed in the overall legislation dealing with capital gains taxation, sections 1201-1291, so it would be repealed if this entire section of the tax code were eliminated.

27. Specifically, we calculated the revenue generated by any given personal income tax rate for all taxpayers, married as well as single, and chose the rate generating the same revenue as under the current rate structure.

28. In doing so, we left in place the EITC, under the presumption that this poverty alleviation program would be viewed as a separate issue from the overall rate structure.

29. Such a carryback can be of particular value for a small start-up since these losses can be carried back to a tax year in which the individual was still a full-time employee and would be in a much higher tax bracket.

30. Starting from the 2005 law, we found in another simulation, in contrast, that the EITC encourages entrepreneurial risk-taking among those in the upper tax brackets, for whom the new concave kink in figure 2.3 dominates, but discourages risk-taking overall because of more than offsetting effects among those in lower tax brackets, where the effects of the two convex kinks in figure 2.3 dominate.

31. For example, in our data for 2001,80 percent of single filers are either in a 0 percent or a 15 percent tax bracket, whereas this is true for only 60 percent of married couples. In contrast, 2.9 percent of single filers are in the top three tax brackets in that year, whereas 8.3 percent of married couples are in these brackets.

32. Under a Hall-Rabushka tax, taxes on financial income from capital would be eliminated, corporate as well as personal income would face this one flat tax rate, while many of the complicated special provisions in the current law would be repealed.

\section{References}

Andreoni, James, Brian Erard, and Jonathan Feinstein (1998). "Tax Compliance," Journal of Economic Literature, 36:818-860.

Barsky, Robert B., Miles S. Kimball, F. Thomas Juster, and Matthew D. Shaprio (1997). "Preference Parameters and Behavioral Heterogeneity: An Experimental Approach in the Health and Retirement Survey," Quarterly Journal of Economics, 112:537-579.

Bound, John, Clint Cummins, Zvi Griliches, Bronwyn H. Hall, and Adam B. Jaffe (1984). "Who Does R\&D and Who Patents?" in Zvi Griliches (ed.), RED, Patents and Productivity, Chicago, Ill.: University of Chicago Press, pp. 21-54.

Cullen, Julie Berry, and Roger H. Gordon (2005). "Taxes and Entrepreneurial Activity: Theory and Evidence for the U.S.," mimeo. 
Diamond, Peter, and Jonathan Gruber (1997). "Social Security and Retirement in the U.S.," NBER working paper no. 6097.

Feldstein, Martin, Louis Dicks-Mireaux, and James Poterba (1983). "The Effective Tax Rate and the Pretax Rate of Return," Journal of Public Economics, 21:129-158.

Gentry, William M., and R. Glenn Hubbard (2004). "'Success Taxes,' Entrepreneurial Entry, and Innovation," NBER working paper no. 10551.

Hall, Bronwyn, and John Van-Reenen (2000). "How Effective Are Fiscal Incentives for R\&D? A Review of the Evidence," Research Policy, 29:449-469.

Hall, Robert E., and Alvin Rabushka (1995). The Flat Tax, 2d ed. Stanford, Calif.: Hoover Institution Press.

Schumpeter, Joseph (1976). Capitalism, Socialism, and Democracy, 5th ed. London: Allen and Unwin.

Sommerfeld, Ray M., and Sally M. Jones (1991). Federal Taxes and Management Decisions, 2d ed. Homewood, Ill.: Richard D. Irwin, Inc. 
